\title{
Toward pluripotency by reprogramming: mechanisms and application
}

\author{
Tao Wang ${ }^{1,2}$, Stephen T. Warren ${ }^{1}$, Peng Jin ${ }^{1 凶}$ \\ ${ }^{1}$ Department of Human Genetics, Emory University, Atlanta, GA 30322, USA \\ ${ }^{2}$ Genetics and Molecular Biology Graduate Program, Emory University, Atlanta, GA 30322, USA \\ $\triangle$ Correspondence: peng.jin@emory.edu \\ Received August 20, 2013 Accepted September 18, 2013
}

\begin{abstract}
The somatic epigenome can be reprogrammed to a pluripotent state by a combination of transcription factors. Altering cell fate involves transcription factors cooperation, epigenetic reconfiguration, such as DNA methylation and histone modification, posttranscriptional regulation by microRNAs, and so on. Nevertheless, such reprogramming is inefficient. Evidence suggests that during the early stage of reprogramming, the process is stochastic, but by the late stage, it is deterministic. In addition to conventional reprogramming methods, dozens of small molecules have been identified that can functionally replace reprogramming factors and significantly improve induced pluripotent stem cell (iPSC) reprogramming. Indeed, iPS cells have been created recently using chemical compounds only. iPSCs are thought to display subtle genetic and epigenetic variability; this variability is not random, but occurs at hotspots across the genome. Here we discuss the progress and current perspectives in the field. Research into the reprogramming process today will pave the way for great advances in regenerative medicine in the future.
\end{abstract}

KEYWORDS epigenetic reprogramming, induced pluripotent stem cells, embryonic stem cells, disease modeling

\section{INTRODUCTION}

In the development of multicellular organisms, a single fertilized cell gives rise to different types of cells with distinct functions. The classic view of cell fate specification is that the undifferentiated, totipotent or pluripotent state is at the top of the multiple types of differentiated somatic states. Conrad Hal Waddington was the first to describe lineage specification in terms of an epigenetic landscape (Waddington, 1957; Goldberg et al., 2007). Metaphorically, a progenitor cell undergoing terminal differentiation is like a marble rolling down a landscape: the marbles will slide downhill, compete for grooves, and eventually come to rest at the lowest points. These lowest points represent the different cell fates. Since marbles tend not to roll back, when cells become more committed during normal development, the cell differentiation potential becomes more restricted. Because Waddington's model fits well in almost all cases, lineage commitment and differentiation has long been considered unidirectional and irreversible.

However, Gurdon showed that the somatic epigenome can be reprogrammed to pluripotency via nuclear reprogramming (Gurdon et al., 1958). Nuclear reprogramming in mammalian cells was first achieved by somatic cell nuclear transfer (SCNT), which established that a nucleus from an adult somatic cell can be reprogrammed by an unfertilized enucleated oocyte (Wilmut et al., 1997). The SCNT experiment was the first evidence that pluripotency can be restored from terminally differentiated cells, and showed that the developmental process is reversible. Subsequently, another form of reprogramming, cell fusion, in which adult somatic cells are fused with embryonic stem (ES) cells or embryonic germ (EG) cells, was used to reset the somatic epigenome to a pluripotent state (Tada et al., 1997, 2001; Cowan et al., 2005). These experiments raise an unanswered and interesting question: which gene product(s) in an enucleated oocyte, ES cells or EG cells are the critical factors in reprogramming.

By screening 24 pluripotency factors, in 2006, Takahashi and Yamanaka showed that only four factors, Oct4(O), Sox2(S), $\mathrm{KIf} 4(\mathrm{~K})$, and $c-M y c(\mathrm{M})$, when used in combination via retrovirus delivery, can convert somatic fibroblasts to embryonic-like stem cells, or induced pluripotent stem cells (iPSCs) (Fig. 1) (Takahashi and Yamanaka, 2006). Thereafter, forced expression of different combinations of genes was shown to successfully re- 


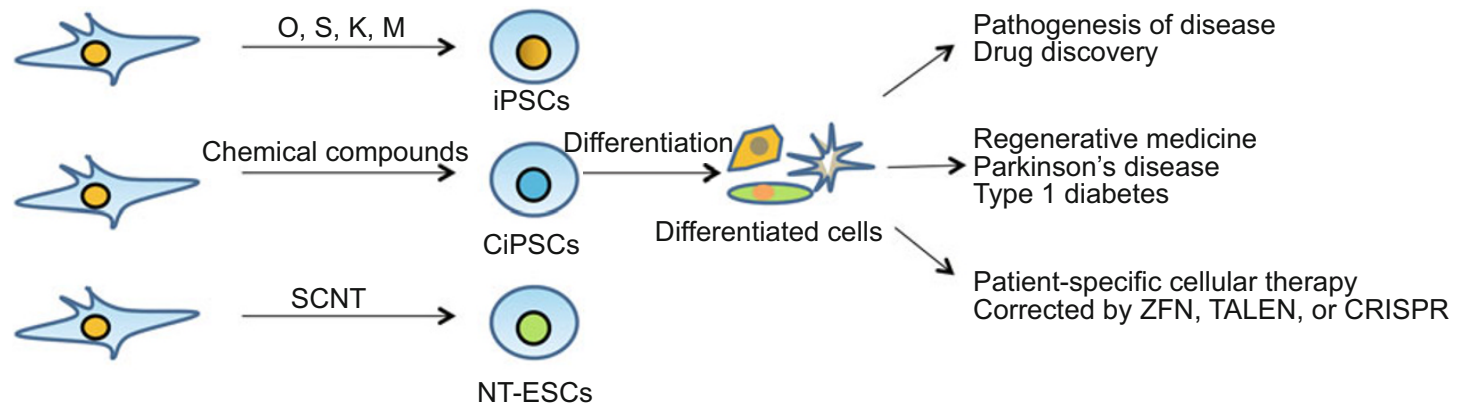

Figure 1. Multiple ways of achieving human pluripotent stages. (1) Transcription factors, such as OCT4, SOX2, KLF4, and c-Myc mediated reprogramming; (2) Reprogramming to chemically induced mouse iPS cells by the small-molecule combination VC6TFZ, and compounds required for human cells remain to be determined.; (3) Reprogramming human somatic cells into pluripotent embryonic stem cells by SCNT. These reprogrammed stem cells have opened new possibilities for human genetic disease modeling, hold tremendous potential for regenerative medicine, and enable patient-specific cellular therapy, by which gene defects in patient-specific iPSCs would be corrected by methods like ZFN, TALEN, or CRISPR.

program fibroblasts, peripheral blood, keratinocytes, and many other types of somatic cells into iPS cells in many species including humans (Takahashi et al., 2007; Aasen et al., 2008; Giorgetti et al., 2009; Haase et al., 2009; Loh et al., 2009; Sun et al., 2009; Seki et al., 2010; Staerk et al., 2010). The delivery methods of these transgenes have expanded as well; among them now are lentivirus, sendai virus, mRNA, episome vectors, and synthetic self-replicative RNA, to name a few (Wernig et al., 2008; Fusaki et al., 2009; Yu et al., 2009; Warren et al., 2010; Yoshioka et al., 2013). Compared with SCNT, the transcription factor-mediated cellular reprogramming process is long, inefficient, and the epigenome variation of iPSCs is large. Many studies have focused extensively on these and illuminated many expected and unexpected mechanisms in this simple scheme, but complicated process. In this review we will summarize the molecular mechanisms of cellular reprogramming, the different methods for efficient reprogramming, and compare iPSC and ESC equivalence.

\section{REPROGRAMMING FACTORS}

Reprogramming is a dedifferentiation process, which is the reverse of cell differentiation. In normal development, pluripotent cells appear transiently; however, ES cells can self-renew and maintain pluripotency in vitro. This suggests ES cells are blocked by particular epigenetic roadblocks. Therefore, during the dedifferentiation process, reprogramming factors push the cells up into the pluripotent state bypassing the epigenetic road blocks. The four factors $\mathrm{O}, \mathrm{S}, \mathrm{K}$, and $\mathrm{M}$ must be expressed in correct stoichiometry that provides a sufficient push, as well as in the right direction. Once they reach the pluripotent state, cells must be blocked by an epigenetic barrier so they can remain. In rare situations as represented by inefficient reprogramming, some cells after reprogramming could be blocked by epigenetic barriers and thus acquire self-renew-ability and become capable of differentiating into multiple lineages.

It is thought that OSKM primarily bind their putative binding sites, alter the corresponding gene expression, and change cell fate. Direct evidence for this is that partially reprogrammed cells, which represent an intermediate reprogramming stage, have failed to activate some pluripotency regulators. In these cells, OCT4, SOX2, and KLF4 primarily targeting is impaired, and genes that are specifically co-bound by O, S, K lack binding and are transcriptionally silenced (Sridharan et al., 2009). Nevertheless, the mechanism would seem to be more complicated, as reprogramming efficiency increases significantly when cells are infected with highly expressed OSKM (Polo et al., 2012). Higher expression of transcription factor is known to increase the strength of nonspecific or low-affinity binding. This phenotype suggests the possibility that low-affinity or random binding sites by OSKM may also play an important role. In tumor cells, elevated c-Myc is found to bind low-affinity E-box-like sequences, which in turn leads to increased levels of transcription (Lin et al., 2012). Similarly, one could predict that OSKM may also have low-affinity binding sites in ES cells, and the binding may have biological consequences. Yet whether it is stochastic binding or low-affinity binding that is crucial or rate limiting for reprogramming is still unknown.

Among the reprogramming factors OCT4, SOX2, and KLF4, most binding events happen primarily in closed chromatin, which consists of condensed heterochromatin (Soufi et al., 2012). OCT4 is a transcription factor of the POU family, and plays a critical role in maintaining self-renewal and undifferentiated state. OCT4 mainly inhibits the expression of differentiationrelated genes in ESCs (Kim et al., 2008; Pardo et al., 2010). When OCT4 is combined with certain chemical compounds, it is sufficient to convert somatic cells into iPSCs. The binding of $\mathrm{O}, \mathrm{S}, \mathrm{K}$ to closed chromatin and the subsequent alteration of it early in reprogramming may therefore be a critical step, because the binding affinity for condensed chromatin for most transcription factors is low, thus they are unable to access the specific sequence. Unlike $\mathrm{O}, \mathrm{S}, \mathrm{K}, \mathrm{c}-\mathrm{Myc}$ is not essential for reprogramming, but it does increase the efficiency of iPS colony formation. For c-Myc, the binding is biased towards active 
and open chromatin, which is marked by H3K4 methylation (Soufi et al., 2012). c-Myc is also found to bind to closed chromatin, but this requires $\mathrm{O}, \mathrm{S}, \mathrm{K}$ binding. These data suggest that $\mathrm{c}-\mathrm{Myc}$ is not a main initiating factor, but rather a positive modulating factor for the other three reprogramming factors.

Activation of endogenous Oct4 and Nanog are crucial for establishing iPSCs. In addition to local regulation such as the alteration of chromatin states by OSKM, DNA looping or nonlocal interaction also determines the pluripotency of the stem cells. There are two potential mechanisms. One is that looping affects the expression of key pluripotent genes by promoting enhancer and promoter interaction. For example, there is a cohesin-complex-mediated intrachromosomal loop that links a downstream enhancer to Oct4's promoter, enabling activation of Oct4 transcription (Zhang et al., 2013). Also, in another study, KLF4 was found to organize long-range chromosomal interactions with the Oct4 locus, suggesting the reprogramming factors like KLF4 can directly regulate long-range interaction (Wei et al., 2013). The second mechanism is represented by Nanog promoter cis regulation. Nanog promoter regions interact with many loci genome-wide and are important for regulating reprogramming via this interaction. A large number of these loci are bound by mediator or cohesin. The establishment of Nanog interactions during reprogramming often precedes the transcriptional up-regulation of associated genes, suggesting the interaction is important for reprogramming. Depletion of these mediators or cohesin results in a disruption of contacts and the acquisition of a differentiation stage interaction pattern (Apostolou et al., 2013).

In addition to OSKM, pluripotency can also be induced by many combinations of transcriptional factors, such as pluripotency associated factors and maternal factors, including $\mathrm{Na}$ nog, Lin28, Glis1, Esrrb, Tbx3, and Utf1 (Yu et al., 2007; Zhao et al., 2008; Feng et al., 2009; Han et al., 2010; Maekawa et al., 2011). In the case of Glis1, it can efficiently generate iPS cells together with OSK. Glis1 is highly expressed in unfertilized oocytes and one-cell stage embryos. When in combination with OSK, Glis1 promotes the expression of multiple proreprogramming factors, including Myc, Nanog, Lin28, Wnt, Essrb, and factors involved in the mesenchymal to epithelial transition (Maekawa et al., 2011). Furthermore, the basal transcription machinery, including the transcription factor IID (TFIID) complex, affects reprogramming efficiency of fibroblasts and is involved in maintaining the pluripotent state. Overexpression of TFIID subunits greatly enhances reprogramming (Pijnappel et al., 2013). All these findings suggest that reprogramming factors need to inhibit lineage specifiers, which are considered to be pluripotency rivals and involved in linear commitment, to convert to pluripotent state. Unexpectedly, a recent study identified eight mesendodermal lineage specifiers as Oct4 substitutes: Cebpa, Hnf4a, Gata3, Gata4, Gata6, Grb2, Pax1, and Sox7 (Shu et al., 2013). Their findings present the first evidence that lineage specifiers can replace reprogramming factors as well as facilitate reprogramming. In mouse blastocyst, Oct4 promotes primitive endoderm development and repress- es trophectoderm fates. Oct4 is required to maintain expression of Gata6, which is involved in mesendodermal lineage specification (Frum et al., 2013). Sox2 represses mesendodermal differentiation and promotes neural ectodermal differentiation (Thomson et al., 2011; Wang et al., 2012). The underlying model is that lineage specifiers, such as Oct4 replacements, act to balance with other mutually exclusive lineage specifiers such as Sox2. Oct4 and its substitutes attenuated the elevated expression of ectodermal genes, such as $D / x 3$, which were triggered by Sox2, KIf4, and c-Myc (Shu et al., 2013). As a result, lineage specifiers synergistically influence the induction of pluripotency.

\section{ELITE, STOCHASTIC, AND DETERMINISTIC MODELS}

Because iPSC reprogramming efficiency is very low, only a small fraction of cells will transform into iPSCs. After Yamanaka's report, some researchers suspected that only a few somatic cells are competent for reprogramming. In this "elite" model, these rare somatic stem cells were contaminated in donor cells and generated the iPSCs, while the differentiated cells would be resistant to reprogramming. However, several lines of evidence show this is not true. First, subsequent improvements in the methods of reprogramming resulted in efficiencies as high as $10 \%-20 \%$. It is unlikely that tissue stem cells comprise this high a percentage of somatic cells. Secondly, iPSC colonies have been derived from terminally differentiated $B$ and $T$ cells (Hochedlinger and Jaenisch, 2002; Seki et al., 2010). In T cells, specific genomic rearrangement of the immunoglobulin locus or the T cell receptor in iPSC cells proved that the cells were derived from mature $\mathrm{B}$ or $\mathrm{T}$ cells, but not the mesenchymal stem cells. Lastly, one study indicated that over $90 \%$ of terminal differentiated $\mathrm{B}$ cells have the potential to generate daughter cells that eventually become iPSCs (Hanna et al., 2009).

Ruling out the elite model, left the question of whether the reprogramming process is stochastic or deterministic. The stochastic model states that somatic cells have to go through the various epigenetic blocks to become iPSCs. In the stochastic model, most differentiated cells have the potential to become iPS cells; however, whether or when a given cell would become an iPSC cell cannot be predicted. In the deterministic model, reprogrammed cells would be generated with a fixed timescale; SCNT is generally considered to fit the deterministic model. More evidence now supports both models for iPSC reprogramming. At early stage, the reprogramming is stochastic as supported by clonal cell analysis (Hanna et al., 2009). Moreover, single-cell gene expression profiling at various stages demonstrates cells from an early stage become iPSCs with variable latency (Buganim et al., 2012). Although reprogramming is stochastic, early activation of some pluripotent genes, such as Esrrb, Utf1, Lin28, and Dppa2, may determine cells to become iPSCs. In somatic cells, many essential pluripotency loci are marked with H3K9me3, such as Nanog, Dppa4, Sox2, Gdf3, and Prdm14 (Samavarchi-Tehrani et al., 2010; Polo et 
al., 2012; Soufi et al., 2012). These genes are refractory to OSKM binding at early stage and are activated later in reprogramming process. Acquisition of the final pluripotent state requires a later stabilization stage marked by the expression of those pluripotency markers (Golipour et al., 2012). Activation of these H3K9me3 marked loci is crucial for reprogramming to full iPSCs, suggesting that, once activated, the cell transits from a stochastic to a deterministic stage (Soufi et al., 2012; Chen et al., 2013). In summary, evidence suggests that during the early stage, the reprogramming is a stochastic process, and when it reaches the late stage, it is deterministic.

\section{EFFECT OF STOICHIOMETRY}

Interestingly, the four factors stoichiometry-the relative expression level of the four factors-can significantly influence both reprogramming efficiency and the quality of the resulting iPS cells. Higher expression of Oct4 than the other three factors will generate more iPSC colonies; the reverse ratio will decrease the efficiency (Papapetrou et al., 2009; Tiemann et al., 2011). Moreover, differences in the order of OSKM polycistronic vector can cause a significant quality difference in iPSCs. When expressed polycistronically in the order of OKSM, the expression of $c-M y c$ and Sox2 are found to be higher, and the Dlk1-Dio3 imprinting locus on mouse chromosome $12 \mathrm{qF} 1$ is aberrantly silenced in most of the iPSC clones (Stadtfeld et al., 2010a). Loss of imprinting at the DIk1-Dio3 locus has been associated with lower pluripotency including poor chimera formation and failure to generate all-iPSC mice by tetraploid complementation. Furthermore, the incidence of tumors in mice created by iPSCs in the order of OKSM is higher (Stadtfeld et al., 2010b). While in the order of OSKM, there is higher expression of Oct4 and Klf4 and lower expression of C-Myc and Sox2, and the reprogrammed iPSCs harbor an active Dlk1Dio3 locus, which is similar to ESCs. The order of OSKM also produces iPS cells that efficiently generate all-iPSC mice by tetraploid complementation, and do not create mice with tumors (Carey et al., 2011). These studies demonstrate that the stoichiometry of reprogramming factors is critical for epigenetic transformation: a skewed combination will lead to poor-quality iPS cells. Importantly, the sequential introduction of reprogramming factors, such as Oct4-KIf4 first, then c-Myc and finally Sox2 at the first several days of reprogramming outperforms simultaneous induction (Liu et al., 2013). This suggests that Oct4 and KIf4 may have higher expression than Sox2 and c$M y c$ at the beginning of the reprogramming process, meaning the stoichiometry may primarily have effects in the early stage of reprogramming.

Once pluripotency is established, on the contrary, a reduced Oct4 expression level seems to enhance pluripotency. Oct $4^{+/-}$ ESCs show increased genome-wide binding of OCT4, particularly at pluripotency-associated enhancers, and increase homogeneous expression of pluripotency transcription factors such as Nanog by reducing Nanog-low and Nanog-negative cells. Thus reduced Oct4 expression enhances ES or iPS cells self-renewal, and delays differentiation (Karwacki-Neisius et al., 2013).

\section{DNA METHYLATION AND DEMETHYLATION}

The iPSC methylome is different from the somatic methylome (Deng et al., 2009; Lister et al., 2009). In mammals, DNA methylation predominantly occurs at cytosine on CpG sites. In embryonic stem cells, up to $25 \%$ of methylation can also occur on non-CpG sites (Lister et al., 2009; Laurent et al., 2010). This is particularly interesting, as it predisposes to the function of non-CpG methylation. Non-CpG methylation tends to occur at exonic regions of actively transcribed regions. The exact function of non-CpG methylation in mammals remained unknown. DNA methylation is catalyzed by DNMT3a/b and maintained by DNMT1 (Leonhardt et al., 1992; Smith and Meissner, 2013). DNMT3a/b is believed to be de novo DNA methyltransferase. DNMT3a/b deficient MEFs can generate iPS cells, and their depletion moderately decreases efficiency compared to wildtype MEFs, suggesting de novo methylation during reprogramming is not essential and plays only a minor role (Pawlak and Jaenisch, 2011). Interestingly, de novo methylation by DNMT3a and DNMT3b is critical during the developmental process and the reprogramming of germ cells (Okano et al., 1999; Kato et al., 2007).

In contrast, DNA demethylation plays a major role in determining iPS cells transformation processes (Fig. 2). During reprogramming, the activation of endogenous Oct4, Nanog, and many other pluripotent genes is accompanied by demethylation of cytosines at their promoter or enhancer regions. Insufficient demethylation of these promoter/enhancer regions leads to partially reprogrammed cells. Furthermore, the inhibition of DNA methylation by DNMT1 inhibitors can increase reprogramming efficiency (Mikkelsen et al., 2008). All this evidence suggests DNA methylation acts as a major barrier to cellular reprogramming, and DNA demethylation plays an important role in successful reprogramming.

There are two proposed mechanisms of DNA demethylation in cells: a DNA replication-independent active DNA demethylation, and a DNA replication-dependent passive DNA demethylation. In the scenario of DNA replication-dependent demethylation, reprogramming factors or some of their targets might antagonize the activity of Dnmt1 or its binding partner, Uhrf1, which in turn leads to the progressive loss of DNA methylation with cell division (Bostick et al., 2007; Sharif et al., 2007). The putative DNA active demthylation pathway was found during last several years. In this pathway, Ten-eleven translocation (TET) proteins sequentially catalyze cytosine to 5 -hydroxycytosine (5hmC), 5 -formylcytosine $(5 \mathrm{fC})$, and 5-carboxylcytosine (5caC) (lyer et al., 2009; Tahiliani et al., 2009; He et al., 2011; Ito et al., 2011). The $5 \mathrm{fC}$ and $5 \mathrm{caC}$ may in turn be removed by TDG and replaced by cytosine via base excision repair (BER) pathway enzymes (He et al., 2011; Maiti and Drohat, 2011; Schiesser et al., 2012). This leads to the proposal that TET proteins may function as DNA demethylases. This cycle was found to be feasible at least biochemically in vitro. TET proteins have been intensively studied in ES cells. TET1 is highly expressed in human ES cells, and Tet1 and Tet2 are highly expressed in mouse ES cells. It has been shown that TET1/2 


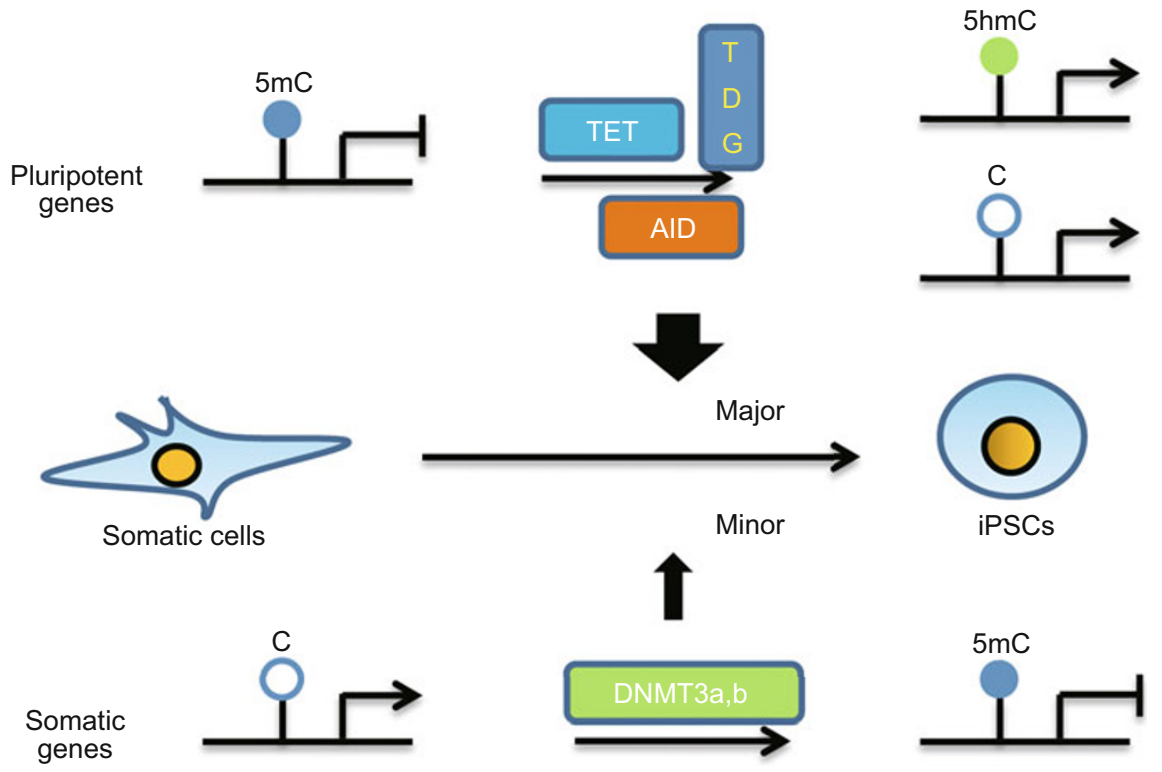

Figure 2. DNA methylation and demethylation during reprogramming. De novo DNA methylation during reprogramming is not essential and plays only a minor role. Depletion of DNMT3a and 3b moderately decreases reprogramming efficiency compared to wild-type cells. In contrast, DNA demethylation plays a major role and determines iPS transformation processes. TET1/2 depletion compromises reprogramming efficiency. A second possible pathway for demethylation involves the deaminase Aid (or Aicda). Aid-null somatic cells fail to stabilize the pluripotency in the later stage during the reprogramming process.

depletion will compromise reprogramming efficiency (Doege et al., 2012; Costa et al., 2013; Gao et al., 2013; Wang et al., 2013), although TET1 and TET2 proteins are not required for essential pluripotency, and are dispensable for maintaining ES cells. One possible mechanism is that TET1 and TET2 interact with NANOG, enhancing the demethylation of Oct4 and other pluripotent gene promoters and enhancers. Specifically, one study showed that Tet1 could replace Oct4, to induce iPSCs (Gao et al., 2013). Interestingly, in human iPSCs, TET2 is not expressed. Whether TET2 has a unique role during reprogramming in mouse ES cells remains unknown. In another model, the deaminase Aid (or Aicda) was proposed recently to play a role in demethylation. It can demethylate the NANOG and OCT4 promoters after cell fusion of mouse ESCs and human fibroblasts (Bhutani et al., 2010; Popp et al., 2010). Furthermore, Aid, through the regulation of Mbd4 and Gadd45, is involved in DNA demethylation in zebrafish (Rai et al., 2008). However, because Aid expression is low in ESCs and iPSCs, whether it has major role in iPS cell reprogramming is unclear. Recently, Aid was reported to act to remove epigenetic memo$r y$, and Aid-null somatic cells fail to stabilize pluripotency in the later stage of the reprogramming process (Kumar et al., 2013). Further research should reveal to what extent active demethylation contributes to overall DNA demethylation.

\section{MicroRNA IN SOMATIC REPROGRAMMING}

MicroRNAs are a family of small non-coding RNAs that bind to partially complementary sequences in messenger RNAs, inducing mRNA degradation or translational silencing (Bar- tel, 2009). Changing somatic cell fate to a pluripotent state requires a complete chromatin reorganization to allow the activation of an endogenous program that sustains self-renewal while preventing differentiation. The reprogramming is accompanied by miRNA expression changes. miRNAs have been implicated in the regulation of the self-renewal and differentiation potential of pluripotent stem cells. For example, Dgcr8null mESCs, in which miRNA biogenesis is impaired, have a reduced proliferation rate, and fail to induce differentiation (Wang et al., 2007). Thus, it is not surprising that a subset of miRNAs is required for efficient and essential reprogramming, while others act as reprogramming "roadblocks". MiRNAs required for efficient and essential reprogramming have similar targeting sequences, and may therefore regulate downstream targets cooperatively. Examples include miR-291-3p, miR-294, miR-295, and miR-302d, which increase reprogramming efficiency with Oct4, KIf4, and Sox2 (Judson et al., 2009). These miRNAs are the ES cell-specific cell cycle regulating micorRNAs, which increase reprogramming by accelerating the $G_{1}$ to $S$ phase transition during cell cycle (Wang et al., 2008). In contrast, overexpressing "roadblock miRNAs", like miR-21 and miR-29a, impede reprogramming (Yang et al., 2011). The p53 and ERK1/2 pathways are regulated by miR-21 and miR-29, which in turn modulate reprogramming.

Interestingly, studies have shown that miRNAs alone, without any exogenous factors, can generate iPS cells, possibly even more effectively than transcription factors (Anokye-Danso et al., 2011; Miyoshi et al., 2011). The first study employed a lentivirus delivery system producing miRNA cluster 302/367. 
MiR367 expression activates Oct4 gene expression and suppresses Hdac2. Moreover, miR-302-targeted co-suppression of four epigenetic regulators, AOF2 (KDM1/LSD1), AOF1, MECP1-p66, and MECP2, could cause global DNA demethylation (Lin et al., 2011). The second study directly transfected mature miRNAs with a combination of miR-200c, miR-302s, and miR-369s family miRNAs. Both approaches successfully produced mouse and human iPS cells from fibroblasts. Nevertheless, there is a discrepancy for miRNA cluster 302/367 in reprogramming. In MEFs by piggybac transfer, microRNA cluster 302/367 could not generate iPSCs (Lu et al., 2012), while another study using human adipose stem cells failed to produce iPSCs by delivering miRNA-302s alone (Hu et al., 2013). These discrepancies could be caused by different delivering systems. For example, it was found that miR-302-induced reprogramming is dosage dependent (Lin et al., 2011), so the microRNA concentration must be within a specific range.

\section{SMALL MOLECULE-MEDIATED REPROGRAMMING}

Conventional reprogramming methods use viruses or transgenes, which not only pose the risk of future reactivation, but also can cause insertion mutagenesis. As a result, conventional reprogramming methods result in iPS cells that are potentially tumorigenic. This risk of cancer may limit iPSC clinical applications. Furthermore, iPSCs may trigger immune rejections (Zhao et al., 2011). However, two recent reports contradict the finding that autologous iPSCs are immunogenic, suggesting some iPSC lines may have negligible or no immunogenicity (Araki et al., 2013; Guha et al., 2013). Nevertheless, a chemical approach that uses small molecules to generate iPS cells may reduce these safety concerns about them. First, chemical approaches are presumably non-immunogenic. In addition, small molecules can easily pass through cell membranes, so they can be removed after they have initiated the reprogramming. Using proper compounds like those are FDA approved should minimize the risk of mutation. To date, dozens of small molecules have been identified that can functionally replace reprogramming factors and significantly improve iPSC reprogramming (Huangfu et al., 2008a, 2008b; Shi et al., 2008a, 2008b; $\mathrm{Li}$ et al., 2009). They primarily target cell signaling pathways, such as the TGF $\beta$ pathway, and nuclear epigenetic factors. One example is BIX-01294, a methyltransferase G9a inhibitor, which can replace Sox2 and c-Myc for reprogramming (Shi et al., 2008a, 2008b). A-83-01, a TGF $\beta$ receptor inhibitor, enhances MEF reprogramming; in combination with $\mathrm{AMI}-5$, a protein arginine methyltransferase inhibitor, it enables reprogramming of MEFs transduced with Oct4 only (Yuan et al., 2011).

Many studies have managed to reduce the number of genes needed to reprogram cells by using small-molecule chemical compounds, but those cases always required Oct4. Recently, iPS cells were created using chemical compounds only; these were called chemically induced iPS cells (CiPSC) (Fig. 1) (Hou et al., 2013). Using a cocktail of seven compounds, this group was able to get $0.2 \%$ of cells to convert, with efficiency comparable to those from standard iPS production techniques. Moreover, the chemical factors were able to induce iPSCs from both mouse embryonic fibroblasts and adult fibroblasts. These small molecules include: $\mathrm{CHIR}$, a glycogen synthase kinase 3 inhibitor; 616452, a TGF-beta inhibitor; FSK, a cAMP agonist; DZNep, an S-adenosylhomocysteine hydrolase inhibitor; TTNPB, a synthetic retinoic acid receptor ligand; valproic acid, a histone deacetylase inhibitor; and tranylcypromine (or Parnate), an inhibitor of lysine-specific demethylase 1. Some of these inhibitors target unexpected pathways, which will reveal other unknown aspects of the reprogramming process. Nevertheless, a detailed comparison of the CiPS and ES cells is needed to determine whether there are subtle differences between them and whether these differences are functionally important for downstream applications.

\section{iPSC AND ESC DIFFERENCES}

iPSCs are functionally equivalent to ESCs. ESCs and iPSCs share key features of pluripotency, including the expression of pluripotency markers, the ability to differentiate into germ layers, teratoma formation in immunodeficient mice, and tetraploid complementation for mouse iPS cells. The key question is whether there are subtle differences between iPSCs and ESCs, and if so, does this lead to biological consequences. The transcriptomes, proteomes, and epigenomes of ESCs and iPSCs have been compared, and results suggest iPSCs may be different from ESCs, leading to concerns about the differentiation potentials of each individual line and the safety of iPSCs for therapeutic applications (Chin et al., 2009; Bock et al., 2011; Lister et al., 2011; Nazor et al., 2012; Ruiz et al., 2012; Liang and Zhang, 2013; Wang et al., 2013). Here we will explore the issue from an epigenetic perspective. The study results above have led to three models of the equivalence between iPSCs and ESCs. The first model states that there are small but consistent differences between ESCs and iPSCs (Chin et al., 2009; Stadtfeld et al., 2010a); in this model, the differences are unique to iPSCs or to ESCs, and thus could be used as a marker to distinguish iPSCs from ESCs. As discussed earlier, the Dlk3-Dio locus was believed to be inactive in mouse iPSCs and was proposed as a marker of iPSCs; however, it turned out the phenotype was caused by a skewed expression level of reprogramming factors. The second model states that iPSCs and ESCs should be treated as two largely overlapping groups that share unique genetic and epigenetic features. In this model, iPSCs show more epigenetic variance, and each iPSC may represent a unique epigenetic status with variable differentiation potential; however, each individual iPSC line cannot be distinguished from ESC lines (Bock et al., 2011; Kim et al., 2011; Lister et al., 2011). Therefore, based on these observations, many people believe there are no differences between the iPSC and ESC populations. A third model, and perhaps the more likely one, given new evidence, is that iPSCs display subtle genetic and epigenetic variability. Most importantly, this variability is not random, but only occurs at certain genes or 
loci, forming aberrant reprogramming hotspots. Not all iPSCs have aberrant events in all these hotspots, but experience events in different combinations of hotspots. For example, hotspot regions with incomplete $5 \mathrm{hmC} / \mathrm{non}-\mathrm{CG}$ methylation tend to cluster in telomere-proximal regions (Wang et al., 2013). Also, in a separate study, gene expression in some iPSCs with aberrant $5 \mathrm{hmC}$ in these genes is different than in ESCs (Ruiz et al., 2012). An intriguing finding is that megabase domains of H3K9me3, which impairs OSKM binding and reprogramming, largely overlap with 20 reprogramming hotspots (Soufi et al., 2012). These H3K9me3 domains are refractory to OSKM binding at the initial 24 hours after reprogramming. This suggests a possible mechanism: these reprogramming hotspots are resistant to OSKM binding, fail to recruit histone demethylase, and are subsequently incapable of initiating TET and DNMT3a/b recruitment. There are fewer aberrant hotspots than megabase domains of $\mathrm{H} 3 \mathrm{~K} 9 \mathrm{me} 3$, suggesting that malfunction of those aberrant hotspots is less critical for iPS cell survival.

\section{DISEASE MODELING AND DIFFERENTIATION}

\section{Disease modeling}

iPS technology has opened new possibilities for human genetic disease modeling. Before the iPSC era, obtaining human pluripotent stem cells carrying a particular genetic mutation was mired in ethnical issues, because it required isolating ES cells from and the destruction of blastocysts (Revazova et al., 2007). Now, by reprogramming cells from a simple skin biopsy or blood, researchers can generate iPS cells from patients with any disease. iPS technology is not merely a replacement for hESC study, because it overcomes two obstacles associated with hESCs: ethical concerns about the use of human embryos and potential immune rejection after non-autologous therapeutic transplantation.

The possibility of generating pluripotent cells from patient somatic cells and subsequently differentiating them into the desired cell types will give us new insights into the pathogenesis of a broad spectrum of diseases (Park et al., 2008; Chambers et al., 2009; Merkle and Eggan, 2013). iPS cell lines from patients with different syndromes have been successfully established and differentiated into defective cell types related to disease (Park et al., 2008; Onder and Daley, 2012; Cherry and Daley, 2013). By comparing disease specific iPS cell lines to their healthy or normal counterparts, we can study the biological mechanisms for genetic variants that affect the risk and progression of the disease. Using this approach has yielded novel insights into various diseases with either Mendelian or complex inheritance, among them Alzheimer's disease (Yagi et al., 2011; Israel et al., 2012; Kondo et al., 2013), Parkinson's disease (Park et al., 2008; Soldner et al., 2009; Hargus et al., 2010; Liu et al., 2012), amyotrophic lateral sclerosis (ALS) (Dimos et al., 2008; Mitne-Neto et al., 2011), Down syndrome (Li et al., 2012), and schizophrenia (Brennand et al., 2011). The most rigorous way to study the effects of genetic variants in human disease would be the generation of isogenic iPSCs, which differs only in the mutation and has the same genetic background. These disease-specific iPS cells and isogenic control cells would also enable screening for novel drugs (Engle and Puppala, 2013). In addition, human disease cell types derived from iPSCs would be more relevant for toxicological testing during the drug development process, compared with the established cancer origin cell types or animal models used now.

Reprogramming of somatic cells into iPS cells also holds tremendous promise for regenerative medicine, the process of replacing damaged tissue. iPSCs can potentially differentiate into any type of cell, and since they are genetically identical to the patients, presumably will not be immunogenic. This holds out the hope of treating patients who need regenerative therapies, including disorders characterized by the loss or destruction of cells or tissues, such as the loss of dopaminergic neurons in Parkinson's disease, autoimmune destruction of beta cells in type 1 diabetes, and spinal cord injury, to name a few (Yu et al., 2013). In the case of Parkinson's disease, a degenerative disorder of the central nervous system, patients progressively lose nerve cells that produce dopamine, causing a loss of motor function. In this new avenue of treatment, the aim is to create iPS cells from a patient, differentiate these cells into the dopamine-producing neurons that have been destroyed by disease, and transplant the cells created in the dish back into the patient's brain.

iPSCs will also be valuable for providing patient-specific cellular therapy by generating autologous iPS cells through reprogramming. In this method, gene defects in patient-specific iPSCs would be corrected by methods like ZFN, TALEN, or CRISPR (Meng et al., 2008; Perez et al., 2008; Cermak et al., 2011; Miller et al., 2011; Cong et al., 2013; Gaj et al., 2013; Jinek et al., 2013; Mali et al., 2013), the iPSCs differentiated into the disease-relevant cells, and the cells returned back to the patient. This avenue of therapy will offer the prospect of treatments for a broad range of disorders. For example, using a ZFN technology, researchers reported a sequence of events for successfully correcting a mutation in human iPSCs derived from individuals with a1-antitrypsin deficiency (A1ATD) due to a point mutation (Glu342Lys) in a1-antitrypsin (Yusa et al., 2011). A1ATD is an autosomal recessive disorder that results in liver cirrhosis and represents the most common inherited metabolic disease of the liver. Researchers first took adult skin cells, reprogrammed the adult cells to iPSCs, corrected the gene mutation in both alleles with ZFN, and differentiated the cells in vitro into hepatocyte-like cells. They demonstrated that these corrected hepatocyte-like cells were able to colonize the liver in mouse and had functional activities. In addition to ZFN, TALEN or CRISPR genome engineering methods, gene correction can also be achieved by helper-dependent adenoviral vectors (HDAdVs) (Suzuki et al., 2008). In the HDAdV based approach, gene correction is achieved through targeted integration via homologous recombination by normal copy of genes delivered by HDAdv virus. For example, laminopathyassociated LMNA mutations, hemoglobinopathy-causing mutations, and LRRK2 mutation of Parkinson's disease in Patient- 
Specific iPSCs were shown successfully corrected by this method (Li et al., 2011; Liu et al., 2011, 2012).

It is important to mention that all of these genome-editing approaches still need further development for treating diseases, as off-target events have to be paid particular attention. It was found that significant off-target mutagenesis can be induced by ZFN, TALEN, and CRISPR. In one study, many off-target sites (up to 5 nucleotides difference compared with target sequence) were found mutagenized with frequencies comparable to or even higher than those observed at the target site (Fu et al., 2013). Therefore, carefully defined and improved methods need to take consideration before treating human diseases. Furthermore, as mentioned earlier, reprogramming methods may cause genetic and epigenetic abnormalities that could take place during reprogramming (Gore et al., 2011; Hussein et al., 2011; Lister et al., 2011), which in turn increase potential tumorigenicity and possible immunogenicity when used in cell therapy (Miura et al., 2009; Zhao et al., 2011; Araki et al., 2013; Guha et al., 2013). Even though chemical compounds or integration free method induced iPS cells may bypass insertion mutagenesis, the epigenetic abnormalities, tumorigenicity, and immunogenicity of transplanted cells remained to be determined. Taken together, continuous development of safer iPSCs is still an important task in the future.

\section{iPSC differentiation}

One of the important challenges for differentiating iPS cells into somatic cells are developing better methods to promote the maturation of differentiated cells to resemble the adult cells. The standard protocol for differentiation relies on embryoid body formation, feeder co-culture, and selective conditions. But it leads to long differentiation process, low yields, and possible heterogeneity of differentiated cells. Small-molecule compounds that targeting developmental pathways, including Wnt, FGF, Notch, and BMP, have been shown to successfully guide iPS cells differentiation. Together with standard embryonic body and feeder co-culture based methods or even alone, the application with chemical compounds greatly facilitate the differentiation process. The key is that applying these molecules either induce or block cell differentiation toward neuroectoderm, trophectoderm, mesoderm, or endoderm lineages.

The use of hPSCs differentiated toward specific lineage such as central nervous system lineages has been of particular interest. For example, the synergistic action of two inhibitors of SMAD signaling, Noggin and SB431542, is sufficient to induce rapid and efficient neural conversion of stem cells in culture. It can also bypass the need for embryoid body based process (Chambers et al., 2009). Studies have successfully generated cell types related with neuron specific disorders. Protocols generating specific neuron types have been created, such as midbrain dopamine neurons in Parkinson's disease (Kriks et al., 2011), motor neurons in ALS (Dimos et al., 2008), and spinal muscular atrophy (Ebert et al., 2009). Furthermore, there is also a considerable progress on differentiating cortical neurons
(Shi et al., 2012; Espuny-Camacho et al., 2013; Maroof et al., 2013), such as pyramidal neurons and cortical interneurons, which are critical for modeling schizophrenia, autism.

In addition to neuronal lineage differentiation, significant progresses have also been made in the differentiation of iP. SCs towards many other cell types including cardiovascular fate, especially into cardiomyocytes, smooth muscle cells, and endothelial cells (Kattman et al., 2011; Cheung et al., 2012; Lian et al., 2012; Minami et al., 2012; Cao et al., 2013). These cells will be valuable applications in vascular diseases such as congenital vascular malformation, with abnormal blood vessels occur at birth. In this scenario, stem cell-based transplantation therapy aims to repair injured cardiovascular tissue with differentiated cells. Together, with our improved understanding of the developmental mechanisms, better and efficient methods will be developed to generate target cell types.

\section{CONCLUDING REMARKS}

Taken together, reprogramming by transcriptional factors not only supports the idea that cell fate changes can be bidirectional and reversible, but also opens new opportunities for the study of cell transdifferentiation. Importantly, studying iPSCs has broadened our understanding of cellular differentiation/ dedifferentiation mechanisms, also yielding valuable information for disease modeling and clinical applications. The recently created all-chemically induced iPS cells will facilitate this application process. We know iPS cells are not exactly equal to ES cells, and whether the subtle differences are consequential for iPSC clinical applications remains unclear. Recently, researchers achieved the reprogramming of human somatic cells into pluripotent embryonic stem cells by SCNT (Tachibana et al., 2013), making an important step for iPSC study (Fig. 1). It will be interesting to see whether stem cells derived from SCNT are more like embryonic stem cells.

\section{ACKNOWLEDGEMENTS}

We thank Cheryl Strauss, Michael Santoro, and Helena Gong at the Department of Human Genetics for helpful reading of the manuscript. This study was supported by the National Institutes of Health (NS079625 and HD073162 to P.J.).

\section{ABBREVIATIONS}

CiPSC, chemically induced iPS cells; EG, embryonic germ; ES, embryonic stem; iPSC, induced pluripotent stem cell; SCNT, somatic cell nuclear transfer; TET, ten-eleven translocation

\section{COMPLIANCE WITH ETHICS GUIDELINES}

Tao Wang, Stephen T. Warren and Peng Jin declare that they have no conflict of interest.

\section{REFERENCES}

Aasen, T., Raya, A., Barrero, M.J., Garreta, E., Consiglio, A., Gonzalez, F., Vassena, R., Bilic, J., Pekarik, V., Tiscornia, G., et al. (2008). Ef- 
ficient and rapid generation of induced pluripotent stem cells from human keratinocytes. Nat Biotechnol 26, 1276-1284.

Anokye-Danso, F., Trivedi, C.M., Juhr, D., Gupta, M., Cui, Z., Tian, Y., Zhang, Y., Yang, W., Gruber, P.J., Epstein, J.A., et al. (2011). Highly efficient miRNA-mediated reprogramming of mouse and human somatic cells to pluripotency. Cell Stem Cell 8, 376-388.

Apostolou, E., Ferrari, F., Walsh, R.M., Bar-Nur, O., Stadtfeld, M., Cheloufi, S., Stuart, H.T., Polo, J.M., Ohsumi, T.K., Borowsky, M.L., et al. (2013). Genome-wide chromatin interactions of the Nanog locus in pluripotency, differentiation, and reprogramming. Cell Stem Cell 12, 699-712.

Araki, R., Uda, M., Hoki, Y., Sunayama, M., Nakamura, M., Ando, S., Sugiura, M., Ideno, H., Shimada, A., Nifuji, A., et al. (2013). Negligible immunogenicity of terminally differentiated cells derived from induced pluripotent or embryonic stem cells. Nature 494, 100-104.

Bartel, D.P. (2009). MicroRNAs: target recognition and regulatory functions. Cell 136, 215-233.

Bhutani, N., Brady, J.J., Damian, M., Sacco, A., Corbel, S.Y., and Blau, H.M. (2010). Reprogramming towards pluripotency requires AIDdependent DNA demethylation. Nature 463, 1042-1047.

Bock, C., Kiskinis, E., Verstappen, G., Gu, H., Boulting, G., Smith, Z.D., Ziller, M., Croft, G.F., Amoroso, M.W., Oakley, D.H., et al. (2011). Reference Maps of human ES and iPS cell variation enable high-throughput characterization of pluripotent cell lines. Cell 144, 439-452.

Bostick, M., Kim, J.K., Esteve, P.O., Clark, A., Pradhan, S., and Jacobsen, S.E. (2007). UHRF1 plays a role in maintaining DNA methylation in mammalian cells. Science 317, 1760-1764.

Brennand, K.J., Simone, A., Jou, J., Gelboin-Burkhart, C., Tran, N., Sangar, S., Li, Y., Mu, Y., Chen, G., Yu, D., et al. (2011). Modelling schizophrenia using human induced pluripotent stem cells. Nature 473, 221-225.

Buganim, Y., Faddah, D.A., Cheng, A.W., Itskovich, E., Markoulaki, S., Ganz, K., Klemm, S.L., van Oudenaarden, A., and Jaenisch, R. (2012). Single-cell expression analyses during cellular reprogramming reveal an early stochastic and a late hierarchic phase. Cell 150, 1209-1222.

Cao, N., Liang, H., Huang, J., Wang, J., Chen, Y., Chen, Z., and Yang, H.T. (2013). Highly efficient induction and long-term maintenance of multipotent cardiovascular progenitors from human pluripotent stem cells under defined conditions. Cell Res 23, 1119-1132.

Carey, B.W., Markoulaki, S., Hanna, J.H., Faddah, D.A., Buganim, Y., Kim, J., Ganz, K., Steine, E.J., Cassady, J.P., Creyghton, M.P., et al. (2011). Reprogramming factor stoichiometry influences the epigenetic state and biological properties of induced pluripotent stem cells. Cell Stem Cell 9, 588-598.

Cermak, T., Doyle, E.L., Christian, M., Wang, L., Zhang, Y., Schmidt, C., Baller, J.A., Somia, N.V., Bogdanove, A.J., and Voytas, D.F. (2011). Efficient design and assembly of custom TALEN and other TAL effector-based constructs for DNA targeting. Nucleic Acids Res 39, e82.

Chambers, S.M., Fasano, C.A., Papapetrou, E.P., Tomishima, M., Sadelain, M., and Studer, L. (2009). Highly efficient neural conversion of human ES and iPS cells by dual inhibition of SMAD signaling. Nat Biotechnol 27, 275-280.

Chen, J., Liu, H., Liu, J., Qi, J., Wei, B., Yang, J., Liang, H., Chen, Y., Wu, Y., Guo, L., et al. (2013). H3K9 methylation is a barrier during somatic cell reprogramming into iPSCs. Nat Genet 45, 34-42.

Cherry, A.B., and Daley, G.Q. (2013). Reprogrammed cells for disease modeling and regenerative medicine. Annu Rev Med 64, 277-290.

Cheung, C., Bernardo, A.S., Trotter, M.W., Pedersen, R.A., and Sinha, S. (2012). Generation of human vascular smooth muscle subtypes provides insight into embryological origin-dependent disease susceptibility. Nat Biotechnol 30, 165-173.

Chin, M.H., Mason, M.J., Xie, W., Volinia, S., Singer, M., Peterson, C., Ambartsumyan, G., Aimiuwu, O., Richter, L., Zhang, J., et al. (2009). Induced pluripotent stem cells and embryonic stem cells are distinguished by gene expression signatures. Cell Stem Cell 5, 111-123.

Cong, L., Ran, F.A., Cox, D., Lin, S., Barretto, R., Habib, N., Hsu, P.D., Wu, X., Jiang, W., Marraffini, L.A., et al. (2013). Multiplex genome engineering using CRISPR/Cas systems. Science 339, 819-823.

Costa, Y., Ding, J., Theunissen, T.W., Faiola, F., Hore, T.A., Shliaha, P.V., Fidalgo, M., Saunders, A., Lawrence, M., Dietmann, S., et al. (2013). NANOG-dependent function of TET1 and TET2 in establishment of pluripotency. Nature 495, 370-374.

Cowan, C.A., Atienza, J., Melton, D.A., and Eggan, K. (2005). Nuclear reprogramming of somatic cells after fusion with human embryonic stem cells. Science 309, 1369-1373.

Deng, J., Shoemaker, R., Xie, B., Gore, A., LeProust, E.M., Antosiewicz-Bourget, J., Egli, D., Maherali, N., Park, I.H., Yu, J., et al. (2009). Targeted bisulfite sequencing reveals changes in DNA methylation associated with nuclear reprogramming. Nat Biotechnol 27, 353-360.

Dimos, J.T., Rodolfa, K.T., Niakan, K.K., Weisenthal, L.M., Mitsumoto, H., Chung, W., Croft, G.F., Saphier, G., Leibel, R., Goland, R., et al. (2008). Induced pluripotent stem cells generated from patients with ALS can be differentiated into motor neurons. Science 321 , 1218-1221.

Doege, C.A., Inoue, K., Yamashita, T., Rhee, D.B., Travis, S., Fujita, R., Guarnieri, P., Bhagat, G., Vanti, W.B., Shih, A., et al. (2012). Earlystage epigenetic modification during somatic cell reprogramming by Parp1 and Tet2. Nature 488, 652-655.

Ebert, A.D., Yu, J., Rose, F.F., Jr., Mattis, V.B., Lorson, C.L., Thomson, J.A., and Svendsen, C.N. (2009). Induced pluripotent stem cells from a spinal muscular atrophy patient. Nature 457, 277-280.

Engle, S.J., and Puppala, D. (2013). Integrating human pluripotent stem cells into drug development. Cell Stem Cell 12, 669-677.

Espuny-Camacho, I., Michelsen, K.A., Gall, D., Linaro, D., Hasche, A., Bonnefont, J., Bali, C., Orduz, D., Bilheu, A., Herpoel, A., et al. (2013). Pyramidal neurons derived from human pluripotent stem cells integrate efficiently into mouse brain circuits in vivo. Neuron $77,440-456$.

Feng, B., Jiang, J., Kraus, P., Ng, J.H., Heng, J.C., Chan, Y.S., Yaw, L.P., Zhang, W., Loh, Y.H., Han, J., et al. (2009). Reprogramming of fibroblasts into induced pluripotent stem cells with orphan nuclear receptor Esrrb. Nat Cell Biol 11, 197-203.

Frum, T., Halbisen, M.A., Wang, C., Amiri, H., Robson, P., and Ralston, A. (2013). Oct4 cell-autonomously promotes primitive endoderm development in the mouse blastocyst. Dev Cell 25, 610-622.

Fu, Y., Foden, J.A., Khayter, C., Maeder, M.L., Reyon, D., Joung, J.K., and Sander, J.D. (2013). High-frequency off-target mutagenesis induced by CRISPR-Cas nucleases in human cells. Nat Biotechnol 31, 822-826.

Fusaki, N., Ban, H., Nishiyama, A., Saeki, K., and Hasegawa, M. (2009). 
Efficient induction of transgene-free human pluripotent stem cells using a vector based on Sendai virus, an RNA virus that does not integrate into the host genome. Proc Jpn Acad Ser B Phys Biol Sci 85, 348-362.

Gaj, T., Gersbach, C.A., and Barbas, C.F., 3rd (2013). ZFN, TALEN, and CRISPR/Cas-based methods for genome engineering. Trends Biotechnol 31, 397-405.

Gao, Y., Chen, J., Li, K., Wu, T., Huang, B., Liu, W., Kou, X., Zhang, Y., Huang, H., Jiang, Y., et al. (2013). Replacement of Oct4 by Tet1 during iPSC induction reveals an important role of DNA methylation and hydroxymethylation in reprogramming. Cell Stem Cell 12, 453-469.

Giorgetti, A., Montserrat, N., Aasen, T., Gonzalez, F., Rodriguez-Piza, I., Vassena, R., Raya, A., Boue, S., Barrero, M.J., Corbella, B.A., et al. (2009). Generation of induced pluripotent stem cells from human cord blood using OCT4 and SOX2. Cell Stem Cell 5, 353-357.

Goldberg, A.D., Allis, C.D., and Bernstein, E. (2007). Epigenetics: a landscape takes shape. Cell 128, 635-638.

Golipour, A., David, L., Liu, Y., Jayakumaran, G., Hirsch, C.L., Trcka, D., and Wrana, J.L. (2012). A late transition in somatic cell reprogramming requires regulators distinct from the pluripotency network. Cell Stem Cell 11, 769-782.

Gore, A., Li, Z., Fung, H.L., Young, J.E., Agarwal, S., Antosiewicz-Bourget, J., Canto, I., Giorgetti, A., Israel, M.A., Kiskinis, E., et al. (2011). Somatic coding mutations in human induced pluripotent stem cells. Nature 471, 63-67.

Guha, P., Morgan, J.W., Mostoslavsky, G., Rodrigues, N.P., and Boyd, A.S. (2013). Lack of immune response to differentiated cells derived from syngeneic induced pluripotent stem cells. Cell Stem Cell $12,407-412$.

Gurdon, J.B., Elsdale, T.R., and Fischberg, M. (1958). Sexually mature individuals of Xenopus laevis from the transplantation of single somatic nuclei. Nature 182, 64-65.

Haase, A., Olmer, R., Schwanke, K., Wunderlich, S., Merkert, S., Hess, C., Zweigerdt, R., Gruh, I., Meyer, J., Wagner, S., et al. (2009). Generation of induced pluripotent stem cells from human cord blood. Cell Stem Cell 5, 434-441.

Han, J., Yuan, P., Yang, H., Zhang, J., Soh, B.S., Li, P., Lim, S.L., Cao, S., Tay, J., Orlov, Y.L., et al. (2010). Tbx3 improves the germ-line competency of induced pluripotent stem cells. Nature 463, 10961100.

Hanna, J., Saha, K., Pando, B., van Zon, J., Lengner, C.J., Creyghton, M.P., van Oudenaarden, A., and Jaenisch, R. (2009). Direct cell reprogramming is a stochastic process amenable to acceleration. Nature 462, 595-601.

Hargus, G., Cooper, O., Deleidi, M., Levy, A., Lee, K., Marlow, E., Yow, A., Soldner, F., Hockemeyer, D., Hallett, P.J., et al. (2010). Differentiated Parkinson patient-derived induced pluripotent stem cells grow in the adult rodent brain and reduce motor asymmetry in Parkinsonian rats. Proc Natl Acad Sci U S A 107, 15921-15926.

He, Y.F., Li, B.Z., Li, Z., Liu, P., Wang, Y., Tang, Q., Ding, J., Jia, Y., Chen, Z., Li, L., et al. (2011). Tet-mediated formation of 5-carboxylcytosine and its excision by TDG in mammalian DNA. Science 333, 1303-1307.

Hochedlinger, K., and Jaenisch, R. (2002). Monoclonal mice generated by nuclear transfer from mature $B$ and $T$ donor cells. Nature 415 , 1035-1038.
Hou, P., Li, Y., Zhang, X., Liu, C., Guan, J., Li, H., Zhao, T., Ye, J., Yang, W., Liu, K., et al. (2013). Pluripotent stem cells induced from mouse somatic cells by small-molecule compounds. Science 341 , 651-654.

Hu, S., Wilson, K.D., Ghosh, Z., Han, L., Wang, Y., Lan, F., Ransohoff, K.J., Burridge, P., and Wu, J.C. (2013). MicroRNA-302 increases reprogramming efficiency via repression of NR2F2. Stem Cells 31, 259-268.

Huangfu, D., Maehr, R., Guo, W., Eijkelenboom, A., Snitow, M., Chen, A.E., and Melton, D.A. (2008a). Induction of pluripotent stem cells by defined factors is greatly improved by small-molecule compounds. Nat Biotechnol 26, 795-797.

Huangfu, D., Osafune, K., Maehr, R., Guo, W., Eijkelenboom, A., Chen, S., Muhlestein, W., and Melton, D.A. (2008b). Induction of pluripotent stem cells from primary human fibroblasts with only Oct4 and Sox2. Nat Biotechnol 26, 1269-1275.

Hussein, S.M., Batada, N.N., Vuoristo, S., Ching, R.W., Autio, R., Narva, E., Ng, S., Sourour, M., Hamalainen, R., Olsson, C., et al. (2011). Copy number variation and selection during reprogramming to pluripotency. Nature 471, 58-62.

Israel, M.A., Yuan, S.H., Bardy, C., Reyna, S.M., Mu, Y., Herrera, C., Hefferan, M.P., Van Gorp, S., Nazor, K.L., Boscolo, F.S., et al. (2012). Probing sporadic and familial Alzheimer's disease using induced pluripotent stem cells. Nature 482, 216-220.

Ito, S., Shen, L., Dai, Q., Wu, S.C., Collins, L.B., Swenberg, J.A., He, C., and Zhang, Y. (2011). Tet proteins can convert 5-methylcytosine to 5-formylcytosine and 5-carboxylcytosine. Science 333, 1300-1303.

Iyer, L.M., Tahiliani, M., Rao, A., and Aravind, L. (2009). Prediction of novel families of enzymes involved in oxidative and other complex modifications of bases in nucleic acids. Cell Cycle 8, 1698-1710.

Jinek, M., East, A., Cheng, A., Lin, S., Ma, E., and Doudna, J. (2013). RNA-programmed genome editing in human cells. eLife 2, e00471.

Judson, R.L., Babiarz, J.E., Venere, M., and Blelloch, R. (2009). Embryonic stem cell-specific microRNAs promote induced pluripotency. Nat Biotechnol 27, 459-461.

Karwacki-Neisius, V., Goke, J., Osorno, R., Halbritter, F., Ng, J.H., Weisse, A.Y., Wong, F.C., Gagliardi, A., Mullin, N.P., Festuccia, N., et al. (2013). Reduced Oct4 expression directs a robust pluripotent state with distinct signaling activity and increased enhancer occupancy by Oct4 and Nanog. Cell Stem Cell 12, 531-545.

Kato, Y., Kaneda, M., Hata, K., Kumaki, K., Hisano, M., Kohara, Y., Okano, M., Li, E., Nozaki, M., and Sasaki, H. (2007). Role of the Dnmt3 family in de novo methylation of imprinted and repetitive sequences during male germ cell development in the mouse. Hum Mol Genet 16, 2272-2280.

Kattman, S.J., Witty, A.D., Gagliardi, M., Dubois, N.C., Niapour, M., Hotta, A., Ellis, J., and Keller, G. (2011). Stage-specific optimization of activin/nodal and BMP signaling promotes cardiac differentiation of mouse and human pluripotent stem cell lines. Cell Stem Cell 8 , 228-240.

Kim, J., Chu, J., Shen, X., Wang, J., and Orkin, S.H. (2008). An extended transcriptional network for pluripotency of embryonic stem cells. Cell 132, 1049-1061.

Kim, K., Zhao, R., Doi, A., Ng, K., Unternaehrer, J., Cahan, P., Huo, H., Loh, Y.H., Aryee, M.J., Lensch, M.W., et al. (2011). Donor cell type can influence the epigenome and differentiation potential of human induced pluripotent stem cells. Nat Biotechnol 29, 1117-1119. 
Kondo, T., Asai, M., Tsukita, K., Kutoku, Y., Onsawa, Y., Sunada, Y., Imamura, K., Egawa, N., Yahata, N., Okita, K., et al. (2013). Modeling Alzheimer's disease with iPSCs reveals stress phenotypes associated with intracellular Abeta and differential drug responsiveness. Cell Stem Cell 12, 487-496.

Kriks, S., Shim, J.W., Piao, J., Ganat, Y.M., Wakeman, D.R., Xie, Z., Carrillo-Reid, L., Auyeung, G., Antonacci, C., Buch, A., et al. (2011). Dopamine neurons derived from human ES cells efficiently engraft in animal models of Parkinson's disease. Nature 480, 547-551.

Kumar, R., DiMenna, L., Schrode, N., Liu, T.C., Franck, P., MunozDescalzo, S., Hadjantonakis, A.K., Zarrin, A.A., Chaudhuri, J., Elemento, O., et al. (2013). AID stabilizes stem-cell phenotype by removing epigenetic memory of pluripotency genes. Nature 500 , 89-92.

Laurent, L., Wong, E., Li, G., Huynh, T., Tsirigos, A., Ong, C.T., Low, H.M., Kin Sung, K.W., Rigoutsos, I., Loring, J., et al. (2010). Dynamic changes in the human methylome during differentiation. Genome Res 20, 320-331.

Leonhardt, H., Page, A.W., Weier, H.U., and Bestor, T.H. (1992). A targeting sequence directs DNA methyltransferase to sites of DNA replication in mammalian nuclei. Cell 71, 865-873.

Li, L.B., Chang, K.H., Wang, P.R., Hirata, R.K., Papayannopoulou, T., and Russell, D.W. (2012). Trisomy correction in Down syndrome induced pluripotent stem cells. Cell Stem Cell 11, 615-619.

Li, M., Suzuki, K., Qu, J., Saini, P., Dubova, I., Yi, F., Lee, J., SanchoMartinez, I., Liu, G.H., and Izpisua Belmonte, J.C. (2011). Efficient correction of hemoglobinopathy-causing mutations by homologous recombination in integration-free patient iPSCs. Cell Res 21, 17401744.

Li, W., Zhou, H., Abujarour, R., Zhu, S., Young Joo, J., Lin, T., Hao, E., Scholer, H.R., Hayek, A., and Ding, S. (2009). Generation of human-induced pluripotent stem cells in the absence of exogenous Sox2. Stem Cells 27, 2992-3000.

Lian, X., Hsiao, C., Wilson, G., Zhu, K., Hazeltine, L.B., Azarin, S.M., Raval, K.K., Zhang, J., Kamp, T.J., and Palecek, S.P. (2012). Robust cardiomyocyte differentiation from human pluripotent stem cells via temporal modulation of canonical Wnt signaling. Proc Natl Acad Sci U SA 109, E1848-1857.

Liang, G., and Zhang, Y. (2013). Genetic and epigenetic variations in iPSCs: potential causes and implications for application. Cell Stem Cell 13, 149-159.

Lin, C.Y., Loven, J., Rahl, P.B., Paranal, R.M., Burge, C.B., Bradner, J.E., Lee, T.I., and Young, R.A. (2012). Transcriptional amplification in tumor cells with elevated c-Myc. Cell 151, 56-67.

Lin, S.L., Chang, D.C., Lin, C.H., Ying, S.Y., Leu, D., and Wu, D.T. (2011). Regulation of somatic cell reprogramming through inducible mir-302 expression. Nucleic Acids Res 39, 1054-1065.

Lister, R., Pelizzola, M., Dowen, R.H., Hawkins, R.D., Hon, G., TontiFilippini, J., Nery, J.R., Lee, L., Ye, Z., Ngo, Q.M., et al. (2009). Human DNA methylomes at base resolution show widespread epigenomic differences. Nature 462, 315-322.

Lister, R., Pelizzola, M., Kida, Y.S., Hawkins, R.D., Nery, J.R., Hon, G., Antosiewicz-Bourget, J., O'Malley, R., Castanon, R., Klugman, S., et al. (2011). Hotspots of aberrant epigenomic reprogramming in human induced pluripotent stem cells. Nature 471, 68-73.

Liu, G.H., Qu, J., Suzuki, K., Nivet, E., Li, M., Montserrat, N., Yi, F., Xu, X., Ruiz, S., Zhang, W., et al. (2012). Progressive degeneration of human neural stem cells caused by pathogenic LRRK2. Nature 491, 603-607.

Liu, G.H., Suzuki, K., Qu, J., Sancho-Martinez, I., Yi, F., Li, M., Kumar, S., Nivet, E., Kim, J., Soligalla, R.D., et al. (2011). Targeted gene correction of laminopathy-associated LMNA mutations in patientspecific iPSCs. Cell Stem Cell 8, 688-694.

Liu, X., Sun, H., Qi, J., Wang, L., He, S., Liu, J., Feng, C., Chen, C., Li, W., Guo, Y., et al. (2013). Sequential introduction of reprogramming factors reveals a time-sensitive requirement for individual factors and a sequential EMT-MET mechanism for optimal reprogramming. Nat Cell Biol 15, 829-838.

Loh, Y.H., Agarwal, S., Park, I.H., Urbach, A., Huo, H., Heffner, G.C., Kim, K., Miller, J.D., Ng, K., and Daley, G.Q. (2009). Generation of induced pluripotent stem cells from human blood. Blood 113, 5476-5479.

Lu, D., Davis, M.P., Abreu-Goodger, C., Wang, W., Campos, L.S., Siede, J., Vigorito, E., Skarnes, W.C., Dunham, I., Enright, A.J., et al. (2012). MiR-25 regulates Wwp2 and Fbxw7 and promotes reprogramming of mouse fibroblast cells to iPSCs. PLoS One 7, e40938.

Maekawa, M., Yamaguchi, K., Nakamura, T., Shibukawa, R., Kodanaka, I., Ichisaka, T., Kawamura, Y., Mochizuki, H., Goshima, N., and Yamanaka, S. (2011). Direct reprogramming of somatic cells is promoted by maternal transcription factor Glis1. Nature 474, 225-229.

Maiti, A., and Drohat, A.C. (2011). Thymine DNA glycosylase can rapidly excise 5-formylcytosine and 5-carboxylcytosine: potential implications for active demethylation of CpG sites. J Biol Chem 286, 35334-35338.

Mali, P., Yang, L., Esvelt, K.M., Aach, J., Guell, M., DiCarlo, J.E., Norville, J.E., and Church, G.M. (2013). RNA-guided human genome engineering via Cas9. Science 339, 823-826.

Maroof, A.M., Keros, S., Tyson, J.A., Ying, S.W., Ganat, Y.M., Merkle, F.T., Liu, B., Goulburn, A., Stanley, E.G., Elefanty, A.G., et al. (2013). Directed differentiation and functional maturation of cortical interneurons from human embryonic stem cells. Cell Stem Cell 12, $559-572$.

Meng, X., Noyes, M.B., Zhu, L.J., Lawson, N.D., and Wolfe, S.A. (2008). Targeted gene inactivation in zebrafish using engineered zincfinger nucleases. Nat Biotechnol 26, 695-701.

Merkle, F.T., and Eggan, K. (2013). Modeling human disease with pluripotent stem cells: from genome association to function. Cell Stem Cell 12, 656-668.

Mikkelsen, T.S., Hanna, J., Zhang, X., Ku, M., Wernig, M., Schorderet, P., Bernstein, B.E., Jaenisch, R., Lander, E.S., and Meissner, A. (2008). Dissecting direct reprogramming through integrative genomic analysis. Nature 454, 49-55.

Miller, J.C., Tan, S., Qiao, G., Barlow, K.A., Wang, J., Xia, D.F., Meng, X., Paschon, D.E., Leung, E., Hinkley, S.J., et al. (2011). A TALE nuclease architecture for efficient genome editing. Nat Biotechnol 29, 143-148.

Minami, I., Yamada, K., Otsuji, T.G., Yamamoto, T., Shen, Y., Otsuka, S., Kadota, S., Morone, N., Barve, M., Asai, Y., et al. (2012). A small molecule that promotes cardiac differentiation of human pluripotent stem cells under defined, cytokine- and xeno-free conditions. Cell Rep 2, 1448-1460.

Mitne-Neto, M., Machado-Costa, M., Marchetto, M.C., Bengtson, M.H., Joazeiro, C.A., Tsuda, H., Bellen, H.J., Silva, H.C., Oliveira, A.S., 
Lazar, M., et al. (2011). Downregulation of VAPB expression in motor neurons derived from induced pluripotent stem cells of ALS8 patients. Hum Mol Genet 20, 3642-3652.

Miura, K., Okada, Y., Aoi, T., Okada, A., Takahashi, K., Okita, K., Nakagawa, M., Koyanagi, M., Tanabe, K., Ohnuki, M., et al. (2009). Variation in the safety of induced pluripotent stem cell lines. Nat Biotechnol 27, 743-745.

Miyoshi, N., Ishii, H., Nagano, H., Haraguchi, N., Dewi, D.L., Kano, Y., Nishikawa, S., Tanemura, M., Mimori, K., Tanaka, F., et al. (2011). Reprogramming of mouse and human cells to pluripotency using mature microRNAs. Cell Stem Cell 8, 633-638.

Nazor, K.L., Altun, G., Lynch, C., Tran, H., Harness, J.V., Slavin, I., Garitaonandia, I., Muller, F.J., Wang, Y.C., Boscolo, F.S., et al. (2012). Recurrent variations in DNA methylation in human pluripotent stem cells and their differentiated derivatives. Cell Stem Cell $10,620-634$.

Okano, M., Bell, D.W., Haber, D.A., and Li, E. (1999). DNA methyltransferases Dnmt3a and Dnmt3b are essential for de novo methylation and mammalian development. Cell 99, 247-257.

Onder, T.T., and Daley, G.Q. (2012). New lessons learned from disease modeling with induced pluripotent stem cells. Curr Opin Genet Dev 22, 500-508.

Papapetrou, E.P., Tomishima, M.J., Chambers, S.M., Mica, Y., Reed, E., Menon, J., Tabar, V., Mo, Q., Studer, L., and Sadelain, M. (2009). Stoichiometric and temporal requirements of Oct4, Sox2, Klf4, and c-Myc expression for efficient human iPSC induction and differentiation. Proc Natl Acad Sci U S A 106, 12759-12764.

Pardo, M., Lang, B., Yu, L., Prosser, H., Bradley, A., Babu, M.M., and Choudhary, J. (2010). An expanded Oct4 interaction network: implications for stem cell biology, development, and disease. Cell Stem Cell 6, 382-395.

Park, I.H., Arora, N., Huo, H., Maherali, N., Ahfeldt, T., Shimamura, A., Lensch, M.W., Cowan, C., Hochedlinger, K., and Daley, G.Q. (2008). Disease-specific induced pluripotent stem cells. Cell 134, 877-886.

Pawlak, M., and Jaenisch, R. (2011). De novo DNA methylation by Dnmt3a and Dnmt3b is dispensable for nuclear reprogramming of somatic cells to a pluripotent state. Genes Dev 25, 1035-1040.

Perez, E.E., Wang, J., Miller, J.C., Jouvenot, Y., Kim, K.A., Liu, O., Wang, N., Lee, G., Bartsevich, V.V., Lee, Y.L., et al. (2008). Establishment of HIV-1 resistance in CD4+ T cells by genome editing using zinc-finger nucleases. Nat Biotechnol 26, 808-816.

Pijnappel, W.W., Esch, D., Baltissen, M.P., Wu, G., Mischerikow, N., Bergsma, A.J., van der Wal, E., Han, D.W., Bruch, H., Moritz, S., et al. (2013). A central role for TFIID in the pluripotent transcription circuitry. Nature 495, 516-519.

Polo, J.M., Anderssen, E., Walsh, R.M., Schwarz, B.A., Nefzger, C.M., Lim, S.M., Borkent, M., Apostolou, E., Alaei, S., Cloutier, J., et al. (2012). A molecular roadmap of reprogramming somatic cells into iPS cells. Cell 151, 1617-1632.

Popp, C., Dean, W., Feng, S., Cokus, S.J., Andrews, S., Pellegrini, M., Jacobsen, S.E., and Reik, W. (2010). Genome-wide erasure of DNA methylation in mouse primordial germ cells is affected by AID deficiency. Nature 463, 1101-1105.

Rai, K., Huggins, I.J., James, S.R., Karpf, A.R., Jones, D.A., and Cairns, B.R. (2008). DNA demethylation in zebrafish involves the coupling of a deaminase, a glycosylase, and gadd45. Cell 135, 1201-1212.
Revazova, E.S., Turovets, N.A., Kochetkova, O.D., Kindarova, L.B., Kuzmichev, L.N., Janus, J.D., and Pryzhkova, M.V. (2007). Patientspecific stem cell lines derived from human parthenogenetic blastocysts. Cloning Stem Cells 9, 432-449.

Ruiz, S., Diep, D., Gore, A., Panopoulos, A.D., Montserrat, N., Plongthongkum, N., Kumar, S., Fung, H.L., Giorgetti, A., Bilic, J., et al. (2012). Identification of a specific reprogramming-associated epigenetic signature in human induced pluripotent stem cells. Proc Natl Acad Sci U S A 109, 16196-16201.

Samavarchi-Tehrani, P., Golipour, A., David, L., Sung, H.K., Beyer, T.A., Datti, A., Woltjen, K., Nagy, A., and Wrana, J.L. (2010). Functional genomics reveals a BMP-driven mesenchymal-to-epithelial transition in the initiation of somatic cell reprogramming. Cell Stem Cell 7 , 64-77.

Schiesser, S., Hackner, B., Pfaffeneder, T., Muller, M., Hagemeier, C., Truss, M., and Carell, T. (2012). Mechanism and stem-cell activity of 5-carboxycytosine decarboxylation determined by isotope tracing. Angew Chem Int Ed Engl 51, 6516-6520.

Seki, T., Yuasa, S., Oda, M., Egashira, T., Yae, K., Kusumoto, D., Nakata, H., Tohyama, S., Hashimoto, H., Kodaira, M., et al. (2010). Generation of induced pluripotent stem cells from human terminally differentiated circulating T cells. Cell Stem Cell 7, 11-14.

Sharif, J., Muto, M., Takebayashi, S., Suetake, I., Iwamatsu, A., Endo, T.A., Shinga, J., Mizutani-Koseki, Y., Toyoda, T., Okamura, K., et al. (2007). The SRA protein Np95 mediates epigenetic inheritance by recruiting Dnmt1 to methylated DNA. Nature 450, 908-912.

Shi, Y., Desponts, C., Do, J.T., Hahm, H.S., Scholer, H.R., and Ding, S. (2008a). Induction of pluripotent stem cells from mouse embryonic fibroblasts by Oct4 and Klf4 with small-molecule compounds. Cell Stem Cell 3, 568-574.

Shi, Y., Do, J.T., Desponts, C., Hahm, H.S., Scholer, H.R., and Ding, S. (2008b). A combined chemical and genetic approach for the generation of induced pluripotent stem cells. Cell Stem Cell 2, 525-528.

Shi, Y., Kirwan, P., Smith, J., Robinson, H.P., and Livesey, F.J. (2012). Human cerebral cortex development from pluripotent stem cells to functional excitatory synapses. Nat Neurosci 15, 477-486.

Shu, J., Wu, C., Wu, Y., Li, Z., Shao, S., Zhao, W., Tang, X., Yang, H., Shen, L., Zuo, X., et al. (2013). Induction of pluripotency in mouse somatic cells with lineage specifiers. Cell 153, 963-975.

Smith, Z.D., and Meissner, A. (2013). DNA methylation: roles in mammalian development. Nat Rev Genet 14, 204-220.

Soldner, F., Hockemeyer, D., Beard, C., Gao, Q., Bell, G.W., Cook, E.G., Hargus, G., Blak, A., Cooper, O., Mitalipova, M., et al. (2009). Parkinson's disease patient-derived induced pluripotent stem cells free of viral reprogramming factors. Cell 136, 964-977.

Soufi, A., Donahue, G., and Zaret, K.S. (2012). Facilitators and impediments of the pluripotency reprogramming factors' initial engagement with the genome. Cell 151, 994-1004.

Sridharan, R., Tchieu, J., Mason, M.J., Yachechko, R., Kuoy, E., Horvath, S., Zhou, Q., and Plath, K. (2009). Role of the murine reprogramming factors in the induction of pluripotency. Cell 136, 364-377.

Stadtfeld, M., Apostolou, E., Akutsu, H., Fukuda, A., Follett, P., Natesan, S., Kono, T., Shioda, T., and Hochedlinger, K. (2010a). Aberrant silencing of imprinted genes on chromosome 12qF1 in mouse induced pluripotent stem cells. Nature 465, 175-181.

Stadtfeld, M., Maherali, N., Borkent, M., and Hochedlinger, K. (2010b). 
A reprogrammable mouse strain from gene-targeted embryonic stem cells. Nat Methods 7, 53-55.

Staerk, J., Dawlaty, M.M., Gao, Q., Maetzel, D., Hanna, J., Sommer, C.A., Mostoslavsky, G., and Jaenisch, R. (2010). Reprogramming of human peripheral blood cells to induced pluripotent stem cells. Cell Stem Cell 7, 20-24.

Sun, N., Panetta, N.J., Gupta, D.M., Wilson, K.D., Lee, A., Jia, F., Hu, S., Cherry, A.M., Robbins, R.C., Longaker, M.T., et al. (2009). Feederfree derivation of induced pluripotent stem cells from adult human adipose stem cells. Proc Natl Acad Sci U S A 106, 15720-15725.

Suzuki, K., Mitsui, K., Aizawa, E., Hasegawa, K., Kawase, E., Yamagishi, T., Shimizu, Y., Suemori, H., Nakatsuji, N., and Mitani, K. (2008). Highly efficient transient gene expression and gene targeting in primate embryonic stem cells with helper-dependent adenoviral vectors. Proc Natl Acad Sci U S A 105, 13781-13786.

Tachibana, M., Amato, P., Sparman, M., Gutierrez, N.M., TippnerHedges, R., Ma, H., Kang, E., Fulati, A., Lee, H.S., Sritanaudomchai, H., et al. (2013). Human embryonic stem cells derived by somatic cell nuclear transfer. Cell 153, 1228-1238.

Tada, M., Tada, T., Lefebvre, L., Barton, S.C., and Surani, M.A. (1997). Embryonic germ cells induce epigenetic reprogramming of somatic nucleus in hybrid cells. EMBO J 16, 6510-6520.

Tada, M., Takahama, Y., Abe, K., Nakatsuji, N., and Tada, T. (2001). Nuclear reprogramming of somatic cells by in vitro hybridization with ES cells. Curr Biol 11, 1553-1558.

Tahiliani, M., Koh, K.P., Shen, Y., Pastor, W.A., Bandukwala, H., Brudno, Y., Agarwal, S., Iyer, L.M., Liu, D.R., Aravind, L., et al. (2009). Conversion of 5-methylcytosine to 5-hydroxymethylcytosine in mammalian DNA by MLL partner TET1. Science 324, 930-935.

Takahashi, K., Tanabe, K., Ohnuki, M., Narita, M., Ichisaka, T., Tomoda, K., and Yamanaka, S. (2007). Induction of pluripotent stem cells from adult human fibroblasts by defined factors. Cell 131, 861-872.

Takahashi, K., and Yamanaka, S. (2006). Induction of pluripotent stem cells from mouse embryonic and adult fibroblast cultures by defined factors. Cell 126, 663-676.

Thomson, M., Liu, S.J., Zou, L.N., Smith, Z., Meissner, A., and Ramanathan, S. (2011). Pluripotency factors in embryonic stem cells regulate differentiation into germ layers. Cell 145, 875-889.

Tiemann, U., Sgodda, M., Warlich, E., Ballmaier, M., Scholer, H.R., Schambach, A., and Cantz, T. (2011). Optimal reprogramming factor stoichiometry increases colony numbers and affects molecular characteristics of murine induced pluripotent stem cells. Cytometry A 79, 426-435.

Waddington, C.H. (1957). The strategy of the genes; a discussion of some aspects of theoretical biology (London,, Allen \& Unwin).

Wang, T., Wu, H., Li, Y., Szulwach, K.E., Lin, L., Li, X., Chen, I.P., Goldlust, I.S., Chamberlain, S.J., Dodd, A., et al. (2013). Subtelomeric hotspots of aberrant 5-hydroxymethylcytosine-mediated epigenetic modifications during reprogramming to pluripotency. Nat Cell Biol 15, 700-711.

Wang, Y., Baskerville, S., Shenoy, A., Babiarz, J.E., Baehner, L., and Blelloch, R. (2008). Embryonic stem cell-specific microRNAs regulate the G1-S transition and promote rapid proliferation. Nat Genet 40, 1478-1483.

Wang, Y., Medvid, R., Melton, C., Jaenisch, R., and Blelloch, R. (2007). DGCR8 is essential for microRNA biogenesis and silencing of embryonic stem cell self-renewal. Nat Genet 39, 380-385.
Wang, Z., Oron, E., Nelson, B., Razis, S., and Ivanova, N. (2012). Distinct lineage specification roles for NANOG, OCT4, and SOX2 in human embryonic stem cells. Cell Stem Cell 10, 440-454.

Warren, L., Manos, P.D., Ahfeldt, T., Loh, Y.H., Li, H., Lau, F., Ebina, W., Mandal, P.K., Smith, Z.D., Meissner, A., et al. (2010). Highly efficient reprogramming to pluripotency and directed differentiation of human cells with synthetic modified mRNA. Cell Stem Cell 7 , 618-630.

Wei, Z., Gao, F., Kim, S., Yang, H., Lyu, J., An, W., Wang, K., and Lu, W. (2013). Klf4 organizes long-range chromosomal interactions with the oct4 locus in reprogramming and pluripotency. Cell Stem Cell 13, 36-47.

Wernig, M., Lengner, C.J., Hanna, J., Lodato, M.A., Steine, E., Foreman, R., Staerk, J., Markoulaki, S., and Jaenisch, R. (2008). A drug-inducible transgenic system for direct reprogramming of multiple somatic cell types. Nat Biotechnol 26, 916-924.

Wilmut, I., Schnieke, A.E., McWhir, J., Kind, A.J., and Campbell, K.H. (1997). Viable offspring derived from fetal and adult mammalian cells. Nature 385, 810-813.

Yagi, T., Ito, D., Okada, Y., Akamatsu, W., Nihei, Y., Yoshizaki, T., Yamanaka, S., Okano, H., and Suzuki, N. (2011). Modeling familial Alzheimer's disease with induced pluripotent stem cells. Hum Mol Genet 20, 4530-4539.

Yang, C.S., Li, Z., and Rana, T.M. (2011). microRNAs modulate iPS cell generation. RNA 17, 1451-1460.

Yoshioka, N., Gros, E., Li, H.R., Kumar, S., Deacon, D.C., Maron, C., Muotri, A.R., Chi, N.C., Fu, X.D., Yu, B.D., et al. (2013). Efficient generation of human iPSCs by a synthetic self-replicative RNA. Cell Stem Cell 13, 246-254.

Yu, D.X., Marchetto, M.C., and Gage, F.H. (2013). Therapeutic translation of iPSCs for treating neurological disease. Cell Stem Cell 12, 678-688.

Yu, J., Hu, K., Smuga-Otto, K., Tian, S., Stewart, R., Slukvin, II, and Thomson, J.A. (2009). Human induced pluripotent stem cells free of vector and transgene sequences. Science 324, 797-801.

Yu, J., Vodyanik, M.A., Smuga-Otto, K., Antosiewicz-Bourget, J., Frane, J.L., Tian, S., Nie, J., Jonsdottir, G.A., Ruotti, V., Stewart, R., et al. (2007). Induced pluripotent stem cell lines derived from human somatic cells. Science 318, 1917-1920.

Yuan, X., Wan, H., Zhao, X., Zhu, S., Zhou, Q., and Ding, S. (2011). Brief report: combined chemical treatment enables Oct4-induced reprogramming from mouse embryonic fibroblasts. Stem Cells 29 , 549-553.

Yusa, K., Rashid, S.T., Strick-Marchand, H., Varela, I., Liu, P.Q., Paschon, D.E., Miranda, E., Ordonez, A., Hannan, N.R., Rouhani, F.J., et al. (2011). Targeted gene correction of alpha1-antitrypsin deficiency in induced pluripotent stem cells. Nature 478, 391-394.

Zhang, H., Jiao, W., Sun, L., Fan, J., Chen, M., Wang, H., Xu, X., Shen, A., Li, T., Niu, B., et al. (2013). Intrachromosomal looping is required for activation of endogenous pluripotency genes during reprogramming. Cell Stem Cell 13, 30-35.

Zhao, T., Zhang, Z.N., Rong, Z., and Xu, Y. (2011). Immunogenicity of induced pluripotent stem cells. Nature 474, 212-215.

Zhao, Y., Yin, X., Qin, H., Zhu, F., Liu, H., Yang, W., Zhang, Q., Xiang, C., Hou, P., Song, Z., et al. (2008). Two supporting factors greatly improve the efficiency of human iPSC generation. Cell Stem Cell 3, $475-479$. 